\title{
First study of hormesis effect on mushroom cultivation
}

\author{
Diego Cunha Zied ${ }^{1}$ (D $\cdot$ Fernanda Aparecida Dourado ${ }^{1}$ Eustáquio Souza Dias ${ }^{2}$ • \\ Arturo Pardo-Giménez ${ }^{3}$
}

Received: 3 May 2017 / Accepted: 12 September 2017 / Published online: 5 October 2017

(c) Springer Science+Business Media B.V. 2017

\begin{abstract}
The use of fungicides is common in mushroom cultivation, but no study was carried out applying reduced doses of fungicides in order to increase yield, taking account the hormesis effect. The aim of this manuscript was to verify the effects of different concentrations of fungicides to stimulate the productivity of different strains of Agaricus bisporus. Two stages were developed, an in vitro study to define the best concentration to be applied in the second experiment an agronomic study, which consisted of the application of the selected fungicides, in their respective concentrations, in an experiment carried out in the mushroom chamber. Clearly, the result of the hormesis effect on mushroom cultivation can be verified. The results obtained in the 1st stage of the study (in vitro) were not always reproduced in the 2 nd stage of the study (in vivo). The kresoxim methyl active ingredient may be an important chemical agent, while strain ABI 15/01 may be an extremely important biological agent to increase yield in the study of hormesis effects.
\end{abstract}

Keywords Agaricus bisporus . White button mushroom . Fungicides $\cdot$ Yield $\cdot$ Strains $\cdot$ Concentration

Diego Cunha Zied

dczied@gmail.com

1 Faculdade de Ciências Agrárias e Tecnológicas (FCAT), Universidade Estadual Paulista (UNESP), Câmpus de Dracena, Rod. Cmte João Ribeiro de Barros, km 651, Bairro das Antes, Dracena, SP 17900-000, Brazil

2 Departamento de Biologia (DBI), Universidade Federal de Lavras (UFLA), Campus Universitário, Lavras, MG 37200-000, Brazil

3 Centro de Investigación, Experimentación y Servicios del Champiñón (CIES), C/Peñicas, s/n. Apdo. 63, 16220 Quintanar del Rey, Cuenca, Spain

\section{Introduction}

Environmental agents rarely produce a linear response in biological systems. Regardless of whether it is sunlight, vitamins, or alcohol, there are qualitatively different responses at low and high doses. High doses are generally harmful, while low doses can be considered beneficial (Sagan 1991).

The term "hormesis" is of relatively recent origin. According to Luckey (1982), hormesis was first used in a 1942 publication to describe the stimulation of fungal growth by low concentrations of a naturally occurring antibiotic substance found in tree bark which, at higher concentrations, suppresses fungal growth.

The evidence that a wide variety of synthetic and naturally occurring agents are stimulatory at low doses is now overwhelming. Calabrese et al. (1987) have collected evidence of stimulation (of some form) from exposure to the following agents: chloroform (five studies), essential trace elements (five studies), pesticides (nine studies), heavy metals (13 studies), polychlorinated biphenyls (three studies), antibiotics (eight studies), hydrocarbons (four studies), alcohols and oleates (four studies), miscellaneous (14 studies).

Among the pesticides mentioned previously, the use of fungicides was verified. Fungicide is a term designated to a substance that kills or inhibits the growth of fungi. In the early 1800 s, plant scientists and chemists began the long journey to discover and invent fungicides that would reduce disease losses (Klittich 2008). The first scientific studies on the use of fungicides for the control of mushroom diseases date back to 1950 (Yoder et al. 1951). The availability of efficient fungicides for the mushroom industry is limited not only by stricter regulations, but also by the fact that the pathogen and the crop are both fungi (Gea et al. 2010).

In this sense, several studies have focused on adjusting the ideal dose of fungicides for the effective control of several 
pathogens in mushroom cultivation, also taking into account the emergence of fungicide resistance in pathogenic fungi (Clough 2000; Grogan and Jukes 2003; Gea et al. 2010; Kosanovic et al. 2015).

Although the use of fungicide is common in mushroom cultivation, to our knowledge, no study has been carried out applying low doses of fungicides in order to increase yield, taking account the hormesis effect. Thus, the aim of this manuscript was to verify the effects of different concentrations of fungicides to stimulate the productivity of different strains of Agaricus bisporus.

\section{Materials and methods}

The present manuscript was developed in two stages, an in vivo study to define the best concentration to be applied in the second experiment an agronomic study, which consisted of the application of the selected fungicides, in their respective concentrations, in an experiment carried out in the mushroom chamber.

\section{Selection of the fungicides}

The fungicides were selected according to their active ingredient and mode of action (product 1 -carbendazim, product 2-tebuconazole, product 3-kresoxim methyl, and a commercial mix of the previous active ingredient product 4carbendazim, tebuconazole, and kresoxim methyl, Table 1). It should be noted that in different countries, mushroom growers use a series of fungicides and not only those mentioned in this study. However, the doses used as reference are the same as those used in the commercial cultivation of $A$. bisporus to control Lecanicilium fungicola diseases ( $\mathrm{g}$ of a.i $\mathrm{m}^{-2}$ ). It is pertinent to point out that in some countries, these fungicides are not recommended for commercial application in mushroom cultivation by regulatory agencies.

\section{Strains}

The following strains of A. bisporus were used in the present work: ABI 04/02, ABI 11/16, ABI 11/19, ABI 11/20,
ABI 15/01, and ABI 15/02. The strains ABI 04/02, ABI 11/16, ABI 11/19, ABI 11/20 were previously characterized by Zied et al. (2015). The strains ABI 15/01 and ABI 15/02 were isolated by commercial growers of Mogi das Cruzes, State of São Paulo (April 2015), who had imported them from the USA. The strains are deposited in the public culture collection of Sao Paulo State University, Câmpus de Dracena and accessible to other researchers who are interested in continuing the present research.

\section{First stage}

The in vitro test was carried out using PDA (Difco, Lawrence, USA) as a culture medium. To study hormesis effects, the culture medium was mixed at different concentrations of the fungicides (Table 1) in order to verify the reduction or the stimulation in the mycelial growth of A. bisporus according to the active ingredient (a.i.). The fungicides were dissolved in autoclaved distilled water and added as solutions to molten sterile PDA to obtain the following concentrations: 5500, 550, 55 and $5.5 \mathrm{ppm}$. All fungicide-amended media were prepared $24 \mathrm{~h}$ before use. A $5-\mathrm{mm}$ diameter PDA plug was taken from the growing edge of the fungal colony from each strain and transferred to the center of each Petri dish containing PDA with its respective fungicide treatment. The Petri dishes were incubated at $22^{\circ} \mathrm{C}$ over a period of 12 days. Mycelial growth was determined by measuring two mutually perpendicular diameters after 12 days of incubation.

\section{Second stage}

According to the results obtained in the 1st stage (in vitro) of the project, and in order to verify the hormesis effect on mushroom production, we selected the following concentrations of fungicides: product $2-55$ and $5.5 \mathrm{ppm}$, product 3-55 ppm, and product 4-5.5 ppm. The strains ABI 04/02, ABI 11/16, ABI 15/01, and ABI 15/02 were selected for the in vivo experiment in the mushroom chamber.

Spawns of each strain were produced on sterile sorghum-based substrate (Sorghum bicolor) supplemented with gypsum $\left(160 \mathrm{~g} \mathrm{~kg}^{-1}\right)$ and lime $\left(20 \mathrm{~g} \mathrm{~kg}^{-1}\right)$. All
Table 1 Description of general characteristics and dose (a.i.) applied for the growers in the commercial cultivation of $A$. bisporus

\begin{tabular}{llllll}
\hline Denomination & $\begin{array}{l}\text { Composition } \\
\left(\mathrm{g} \mathrm{l}^{-1}\right)\end{array}$ & $\begin{array}{l}\text { Active ingredient } \\
(\text { a.i. })\end{array}$ & Chemical group & $\begin{array}{l}\text { Dose a.i. } \\
\left(\mathrm{g} \mathrm{m}^{-2}\right)\end{array}$ & Mode of action \\
\hline Product 1 & 500 & Carbendazim & Benzimidazol & 0.0275 & Systemic \\
Product 2 & 200 & Tebuconazole & Triazole & 0.017 & Systemic \\
Product 3 & 500 & Kresoxim methyl & Strobilurin & 0.015 & Contact \\
Product 4 & 200 & Carbendazim+ & Benzimidazol+ & $0.025+$ & Systemic and contact \\
& 100 & Tebuconazole+ & Triazole+ & $0.0125+$ & \\
& 125 & Kresoxim methyl & Strobilurin & 0.01825 & \\
\hline
\end{tabular}


preparation and sterilization procedures were done in accordance with Zied et al. $(2010,2014)$.

The mushroom compost was provided by Compobras Company, Castro, in the State of Paraná. At the end of Phase II, the compost exhibited 68\% humidity, following the quality indicators described by Zied et al. (2011). We inoculated $4 \mathrm{~kg}$ of compost with $40 \mathrm{~g}$ of the respective spawn strain of $A$. bisporus; the compost was then filled into a plastic box, pressed, and incubated at $25^{\circ} \mathrm{C}$ for 15 days. A loamy oxisol-alfisol was used as the casing soil. Soil $\mathrm{pH}$ was adjusted to 7.0 by adding calcium carbonate $\left(10 \mathrm{~kg} \mathrm{~m}^{-3}\right) 20$ days before casing. After this period, soil moisture was adjusted to 30 , and $20 \%$ (V/V) wood charcoal (1-2 cm diameter) was mixed in. The mixture was then pasteurized at $60^{\circ} \mathrm{C}$ for $12 \mathrm{~h}$. The casing layer was added on top of the colonized compost until it reached a height of $4 \mathrm{~cm}$. Three days after casing, the fungicides were applied according to their respective concentrations.

During the first 8 days after casing, compost temperature was maintained at $25{ }^{\circ} \mathrm{C}$, the atmospheric $\mathrm{CO}_{2}$ content below $5000 \mathrm{ppm}$ and the relative humidity at $95 \%$. To initiate primordia, temperature, $\mathrm{CO}_{2}$ content, and humidity were lowered to $19{ }^{\circ} \mathrm{C}, 1000 \mathrm{ppm}$, and $87 \%$, respectively. The mushrooms were harvested every day at their optimal commercial stage of development, corresponding to morphogenetic stages 2, 3, and 4 of the classification established by Hammond and Nichols (1976). Mushroom weight after stipe trimming (cut to remove the casing, approximately $1.5 \mathrm{~cm}$ ) and the total number of mushrooms picked from each box were recorded daily. The yield was calculated as fresh weight (fw) of mushroom divided by fw of compost multiplied by 100 and expressed as \% (Zied et al. 2015).

\section{Experimental design}

In the first stage, four experiments were carried out, each one using a fungicide (product 1,2,3, or 4) in a double factorial design that consisted of 30 treatments (six strains $\times$ four concentrations + control), with six replicates (referring to a Petri dish). In the second stage, an experiment in double factorial design that consisted of 20 treatments (four strains $\times$ five products/concentrations), with six replicates (a box with $4 \mathrm{~kg}$ of compost) was carried out. The results are expressed as mean values \pm standard deviations according to each variable analyzed in the $1 \mathrm{st}$ (mycelial growth) and 2nd stage (yield, weight, and number of mushrooms) of the study. An ANOVA was used to analyze the data, followed by the least significant difference (LSD) test at $\mathrm{p}<0.05$.

\section{Results}

\section{First stage}

Mycelial growth of A. bisporus was completely inhibited, for all strains studied, by the products 2 and 4 in the concentrations of 5550 and $550 \mathrm{ppm}$. Product 3 caused a strong, but not complete reduction of the mycelial growth at the same concentrations, except for strain ABI 11/16, which was completely inhibited for all tested concentrations. Product 1 caused a mild inhibition of mycelial growth in the concentrations of 5550 and $550 \mathrm{ppm}$ (Table 2).

A stimulatory effect was observed for the strains $\mathrm{ABI}$ 04/02, ABI 11/19, ABI 15/01, and ABI 15/02 at 55 ppm of product 2 , increasing mycelial growth by $2.5,3,1$, and $14.5 \%$, respectively, similar statistically with the control. The same stimulatory effect of product 4 at $55 \mathrm{ppm}$ was observed for the strains ABI 15/01 and ABI 15/02, with an increase of mycelial growth by 14.5 and $4.5 \%$, respectively, similar statistically with the control.

Product 2 was the only one that showed a stimulatory effect on mycelial growth at a concentration of $5.5 \mathrm{ppm}$, statistically significant differences for the strain ABI 15/02, with an increase of $45.5 \%$, and without significant differences for the strains ABI 04/02 and ABI 11/19, with increases of 9.0 and $10.2 \%$, respectively, compared to the control.

\section{Second stage}

Only the strain ABI 15/01 showed an increase of yield in the 1 st flush for all products and their respective concentrations, with rates of increase ranging from 10.5 to $32.5 \%$. Strains ABI 04/02 and ABI 11/16 showed an inexpressive increase of yield when products 2 and 4 were used at different concentrations. Strain ABI 15/02 showed a decrease of yield during the 1 st flush for all fungicide treatments (Table 3). These results were not statistically significant, different from the results obtained by the ABI 15/01 strain compared to the other strains that showed high precocity and yield in the 1 st flush.

In the 2 nd flush, product $2(55 \mathrm{ppm})$ and product 4 $(55 \mathrm{ppm})$ showed increases of yield for all strains. The strain ABI 04/02 stood out in the second flush, showing an increase in yield for all fungicide treatments. Similar results were observed for the strain ABI 15/01, except for product 3 (55 ppm), and for ABI 15/02, except for product 2 (5.5 ppm). Strain ABI 15/02 was significantly superior in the 2nd flush.

During the 3rd flush, strain ABI 04/02 kept producing above the control, except for product 4 (55 ppm). The other strains showed a lower yield or an inexpressive difference compared to the control. 
Table 2 Mycelial growth ( $\mathrm{mm}$ ) of A. bisporus strains submitted of the application of different fungicides and their respective concentrations (experiments 1, 2, 3 and 4)

\begin{tabular}{|c|c|c|c|c|c|c|}
\hline & Strains & $5550 \mathrm{ppm}$ & $550 \mathrm{ppm}$ & $55 \mathrm{ppm}$ & $5.5 \mathrm{ppm}$ & Control \\
\hline \multicolumn{7}{|c|}{ (Mycelial growth, mm) } \\
\hline \multirow[t]{6}{*}{ Product 1} & ABI 04/02 & $17.00 \pm 2.73^{\mathrm{a} \mathrm{B}}$ & $20.57 \pm 2.56^{\mathrm{b} \mathrm{B}}$ & $20.66 \pm 1.68^{\mathrm{dB}}$ & $29.03 \pm 3.76^{\mathrm{a} \mathrm{A}}$ & $30.49 \pm 4.17^{\mathrm{c} \mathrm{A}}$ \\
\hline & ABI $11 / 16$ & $21.85 \pm 0.71^{\mathrm{aC}}$ & $29.31 \pm 1.10^{\mathrm{a} B}$ & $33.34 \pm 2.03^{\mathrm{a} B}$ & $32.68 \pm 6.01^{\mathrm{a} \mathrm{B}}$ & $46.25 \pm 5.11^{\mathrm{a} \mathrm{A}}$ \\
\hline & ABI 11/19 & $19.62 \pm 4.17^{\mathrm{aC}}$ & $30.48 \pm 2.86^{\mathrm{a} B}$ & $33.06 \pm 3.47^{\mathrm{a} A B}$ & $33.04 \pm 3.02^{\mathrm{a} A B}$ & $37.94 \pm 2.33^{\mathrm{b} \mathrm{A}}$ \\
\hline & ABI $11 / 20$ & $11.63 \pm 0.72^{\mathrm{bC}}$ & $9.73 \pm 4.28^{\mathrm{c} \mathrm{C}}$ & $24.06 \pm 4.73^{\mathrm{cd} \mathrm{B}}$ & $23.44 \pm 6.59^{\mathrm{b} \mathrm{B}}$ & $35.65 \pm 6.22^{\mathrm{b} \mathrm{A}}$ \\
\hline & ABI $15 / 01$ & $21.53 \pm 3.82^{\mathrm{a} C D}$ & $27.11 \pm 5.19^{\mathrm{a} B}$ & $26.07 \pm 5.28^{\mathrm{bc} \mathrm{BC}}$ & $20.33 \pm 5.40^{\mathrm{b} \mathrm{D}}$ & $39.69 \pm 2.95^{\mathrm{b} \mathrm{A}}$ \\
\hline & ABI $15 / 02$ & $17.11 \pm 2.26^{\mathrm{a} \mathrm{D}}$ & $26.10 \pm 1.05^{\mathrm{aC}}$ & $30.21 \pm 3.31^{\mathrm{ab} \mathrm{BC}}$ & $31.39 \pm 3.77^{\mathrm{a} A \mathrm{~B}}$ & $35.39 \pm 5.39^{\mathrm{b} \mathrm{A}}$ \\
\hline \multirow[t]{6}{*}{ Product 2} & ABI 04/02 & $0^{\mathrm{B}}$ & $0^{\mathrm{B}}$ & $36.23 \pm 17.14^{\mathrm{ab} \mathrm{A}}$ & $38.56 \pm 7.32^{\mathrm{a} \mathrm{A}}$ & $35.37 \pm 7.83^{\mathrm{ab} \mathrm{A}}$ \\
\hline & ABI $11 / 16$ & $0^{\mathrm{C}}$ & $0^{\mathrm{C}}$ & $14.13 \pm 6.72^{\mathrm{c} \mathrm{B}}$ & $20.82 \pm 4.41^{\mathrm{c} \mathrm{AB}}$ & $22.08 \pm 3.73^{\mathrm{c} \mathrm{A}}$ \\
\hline & ABI 11/19 & $0^{\mathrm{B}}$ & $0^{\mathrm{B}}$ & $31.03 \pm 12.07^{\mathrm{b} \mathrm{A}}$ & $33.19 \pm 8.33^{\mathrm{a} \mathrm{A}}$ & $30.11 \pm 12.47^{\mathrm{b} \mathrm{A}}$ \\
\hline & ABI $11 / 20$ & $0^{\mathrm{B}}$ & $0^{\mathrm{B}}$ & $31.14 \pm 2.47^{\mathrm{b} \mathrm{A}}$ & $32.75 \pm 1.29^{\mathrm{ab} \mathrm{A}}$ & $32.96 \pm 1.73^{\mathrm{ab} \mathrm{A}}$ \\
\hline & ABI 15/01 & $0^{\mathrm{B}}$ & $0^{\mathrm{B}}$ & $39.31 \pm 13.17^{\mathrm{aA}}$ & $33.33 \pm 1.00^{\mathrm{a} \mathrm{A}}$ & $38.93 \pm 1.49^{\mathrm{a} \mathrm{A}}$ \\
\hline & ABI $15 / 02$ & $0^{\mathrm{C}}$ & $0^{\mathrm{C}}$ & $20.09 \pm 3.48^{\mathrm{c} \mathrm{AB}}$ & $25.50 \pm 1.42^{\mathrm{bc} \mathrm{A}}$ & $17.54 \pm 3.06^{\mathrm{c} \mathrm{B}}$ \\
\hline \multirow[t]{6}{*}{ Product 3} & ABI 04/02 & $5.20 \pm 2.25^{\mathrm{aD}}$ & $7.37 \pm 2.64^{\mathrm{a} D}$ & $12.23 \pm 4.38^{\mathrm{aC}}$ & $16.84 \pm 1.63^{\mathrm{a} B}$ & $25.91 \pm 3.67^{\mathrm{b} \mathrm{A}}$ \\
\hline & ABI 11/16 & $0^{\mathrm{d} \mathrm{B}}$ & $0^{\mathrm{c} \mathrm{B}}$ & $0^{\mathrm{b} \mathrm{B}}$ & $0^{\mathrm{cB}}$ & $62.93 \pm 5.55^{\mathrm{aA}}$ \\
\hline & ABI $11 / 19$ & $4.83 \pm 1.77^{\mathrm{abC}}$ & $5.46 \pm 0.98^{\mathrm{ab} \mathrm{C}}$ & $10.54 \pm 2.90^{\mathrm{a} B}$ & $12.09 \pm 3.40^{\mathrm{b} \mathrm{B}}$ & $22.34 \pm 3.60^{\mathrm{c} \mathrm{A}}$ \\
\hline & ABI $11 / 20$ & $1.47 \pm 0.65^{\mathrm{cd} \mathrm{D}}$ & $2.48 \pm 0.49^{\mathrm{bc} \mathrm{D}}$ & $11.09 \pm 1.38^{\mathrm{aC}}$ & $16.20 \pm 4.44^{\mathrm{a} B}$ & $23.33 \pm 5.08^{\mathrm{bc} A}$ \\
\hline & ABI 15/01 & $1.91 \pm 0.98^{\mathrm{cd} \mathrm{D}}$ & $4.74 \pm 0.58^{\mathrm{ab} \mathrm{D}}$ & $12.42 \pm 3.55^{\mathrm{a} C}$ & $18.18 \pm 1.95^{\mathrm{a} B}$ & $24.51 \pm 2.61^{\mathrm{bc} \mathrm{A}}$ \\
\hline & ABI $15 / 02$ & $4.60 \pm 2.03^{\mathrm{abc} C}$ & $6.40 \pm 1.25^{\mathrm{aC}}$ & $10.36 \pm 0.86^{\mathrm{a} A B}$ & $9.76 \pm 2.00^{\mathrm{b} B}$ & $13.12 \pm 1.43^{\mathrm{d} \mathrm{A}}$ \\
\hline \multirow[t]{6}{*}{ Product 4} & ABI 04/02 & $0^{\mathrm{B}}$ & $0^{\mathrm{B}}$ & $19.19 \pm 9.03^{\mathrm{c} \mathrm{A}}$ & $14.20 \pm 2.73^{\mathrm{c} \mathrm{A}}$ & $19.55 \pm 1.46^{\mathrm{c} \mathrm{A}}$ \\
\hline & ABI 11/16 & $0^{\mathrm{B}}$ & $0^{\mathrm{B}}$ & $15.97 \pm 5.99^{\mathrm{c} \mathrm{B}}$ & $15.50 \pm 6.55^{\mathrm{c} \mathrm{B}}$ & $29.40 \pm 3.40^{\mathrm{b} \mathrm{A}}$ \\
\hline & ABI 11/19 & $0^{\mathrm{B}}$ & $0^{\mathrm{B}}$ & $26.04 \pm 8.69^{\mathrm{b} \mathrm{A}}$ & $26.10 \pm 6.20^{\mathrm{b} A}$ & $29.14 \pm 4.69^{\mathrm{b} A}$ \\
\hline & ABI $11 / 20$ & $0^{\mathrm{B}}$ & $0^{\mathrm{B}}$ & $39.20 \pm 1.30^{\mathrm{a} \mathrm{A}}$ & $36.19 \pm 3.53^{\mathrm{a} A}$ & $39.96 \pm 1.29^{\mathrm{a} \mathrm{A}}$ \\
\hline & ABI 15/01 & $0^{\mathrm{C}}$ & $0^{\mathrm{C}}$ & $33.81 \pm 8.70^{\mathrm{a} \mathrm{A}}$ & $24.77 \pm 10.62^{\mathrm{b} B}$ & $30.18 \pm 5.43^{\mathrm{b} \mathrm{AB}}$ \\
\hline & ABI 15/02 & $0^{\mathrm{B}}$ & $0^{\mathrm{B}}$ & $21.33 \pm 2.82^{\mathrm{ab} \mathrm{A}}$ & $18.70 \pm 2.86^{\mathrm{c} \mathrm{A}}$ & $20.40 \pm 2.59^{\mathrm{c} \mathrm{A}}$ \\
\hline
\end{tabular}

Each value is expressed as mean \pm standard deviation $(n=6)$. Values followed by different lower case letters within a column and upper case letters within a line are significantly different at $p<0.05$

Total yield results were extremely interesting, highlighting the yield increase of ABI 15/01 strain for all fungicide treatments, in the order of $10,10.5,23$, and $19 \%$, respectively, for product $2(55 \mathrm{ppm})$, product $2(5.5 \mathrm{ppm})$, product $3(55 \mathrm{ppm})$, and product $4(55 \mathrm{ppm})$. Strain ABI $15 / 02$ was the only strain that showed a decrease of total yield for all treatments tested in relation to the control. Strains ABI 15/01 and ABI 15/02 were significantly superior to the other strains, and this result was evidenced in the ABI 15/01 strain by the hormesis effect when the products were applied at a reduced dose.

The increase in total yield of the ABI 15/01 by strain applying product $3(55 \mathrm{ppm})$ and product $4(55 \mathrm{ppm})$ was due to the increase in the weight of the mushrooms harvested and not due to the increase in the number of harvested mushrooms. We also verified that product 4 (55 ppm) tends to increase the weight of the harvested mushrooms, although without statistically significant differences in any case.

\section{Discussion}

Our results clearly verified the hormesis effect on mushroom cultivation. Although this is the first study, we can report that there is a response in the physiological behavior of $A$. bisporus as a function of the strain vs product vs concentration used. The results obtained in the 1st stage of the study in vitro were not always repeated in the 2 nd stage of the study in vivo. The absence of a direct relationship between the laboratory and the field test suggests that the effect of fungicides on mycelial growth does not directly reflect in the mushroom yield. Considering regular crops, the fungicide yield concentration use do be pretty much higher than the IC50 determined by in vitro tests (Reis et al. 2015).

According to the positive results obtained during the 1st stage of the study, where the stimulation on mycelial growth was verified, the strains ABI 04/02, ABI 15/01, and ABI $15 / 02$ were selected for the experiment of mushroom production. In a similar way, products 2 and 4 were selected 
Table 3 Cultivation of A. bisporus strains submitted of the application of different fungicides and their respective concentrations

\begin{tabular}{|c|c|c|c|c|c|c|}
\hline & Strain & Product $255 \mathrm{ppm}$ & Product $25.5 \mathrm{ppm}$ & Product 355 ppm & Product 455 ppm & Control \\
\hline \multirow[t]{4}{*}{ 1st flush (yield, \%) } & ABI $04 / 02$ & $14.25 \pm 8.09^{\mathrm{a}}$ & $12.60 \pm 9.59^{\mathrm{a}}$ & $11.03 \pm 8.16^{\mathrm{b}}$ & $14.20 \pm 2.42^{\mathrm{a}}$ & $14.00 \pm 6.62^{\mathrm{ab}}$ \\
\hline & ABI $11 / 16$ & $2.30 \pm 2.38^{\mathrm{b}}$ & $2.27 \pm 2.20^{\mathrm{b}}$ & $0.05 \pm 0.10^{\mathrm{c}}$ & $1.63 \pm 2.19^{\mathrm{b}}$ & $0.80 \pm 1.79^{c}$ \\
\hline & ABI $15 / 01$ & $18.95 \pm 3.33^{\mathrm{a}}$ & $18.08 \pm 5.16^{\mathrm{a}}$ & $21.70 \pm 3.93^{\mathrm{a}}$ & $19.90 \pm 2.98^{\mathrm{a}}$ & $16.37 \pm 6.54^{\mathrm{a}}$ \\
\hline & ABI 15/02 & $7.24 \pm 6.14^{\mathrm{b}}$ & $5.49 \pm 3.52^{\mathrm{b}}$ & $7.02 \pm 3.82^{\mathrm{b}}$ & $7.28 \pm 5.21^{\mathrm{b}}$ & $9.24 \pm 4.42^{\mathrm{b}}$ \\
\hline \multirow[t]{4}{*}{ 2nd flush (yield, \%) } & ABI 04/02 & $1.32 \pm 0.78^{\mathrm{b}}$ & $1.58 \pm 0.82^{\mathrm{b}}$ & $1.27 \pm 0.78^{\mathrm{b}}$ & $1.12 \pm 1.68^{\mathrm{b}}$ & $0.84 \pm 0.84^{b}$ \\
\hline & ABI $11 / 16$ & $3.86 \pm 1.20^{\mathrm{b}}$ & $2.34 \pm 0.48^{\mathrm{b}}$ & $1.59 \pm 1.51^{\mathrm{b}}$ & $3.00 \pm 1.74^{\mathrm{b}}$ & $2.68 \pm 2.17^{\mathrm{b}}$ \\
\hline & ABI $15 / 01$ & $4.46 \pm 3.26^{\mathrm{b}}$ & $4.70 \pm 1.34^{\mathrm{b}}$ & $2.93 \pm 1.51^{\mathrm{b}}$ & $4.30 \pm 2.37^{b}$ & $3.44 \pm 3.06^{\mathrm{b}}$ \\
\hline & ABI $15 / 02$ & $12.78 \pm 5.09^{\mathrm{a}}$ & $11.16 \pm 5.46^{\mathrm{a}}$ & $12.87 \pm 0.92^{\mathrm{a}}$ & $13.14 \pm 3.14^{\mathrm{a}}$ & $12.03 \pm 4.29^{\mathrm{a}}$ \\
\hline \multirow[t]{4}{*}{ 3rd flush (yield, \%) } & ABI 04/02 & $0.72 \pm 1.03^{\mathrm{ab}}$ & $0.54 \pm 1.21^{\mathrm{b}}$ & $0.50 \pm 0.77^{\mathrm{b}}$ & $0.14 \pm 0.31^{\mathrm{b}}$ & $0.4 \pm 0.89^{\mathrm{b}}$ \\
\hline & ABI $11 / 16$ & $0.20 \pm 0.43^{\mathrm{b}}$ & $0.69 \pm 0.94^{\mathrm{b}}$ & $0.74 \pm 1.12^{\mathrm{ab}}$ & $0.59 \pm 0.63^{\mathrm{ab}}$ & $1.51 \pm 1.10^{\mathrm{ab}}$ \\
\hline & ABI $15 / 01$ & $0.88 \pm 1.30^{\mathrm{ab}}$ & $1.71 \pm 1.49^{\mathrm{ab}}$ & $2.53 \pm 1.51^{\mathrm{a}}$ & $2.15 \pm 1.91^{\mathrm{a}}$ & $2.30 \pm 0.46^{\mathrm{a}}$ \\
\hline & ABI $15 / 02$ & $2.37 \pm 2.68^{\mathrm{a}}$ & $3.07 \pm 2.26^{\mathrm{a}}$ & $1.31 \pm 0.90^{\mathrm{ab}}$ & $1.98 \pm 2.81^{\mathrm{a}}$ & $2.26 \pm 1.62^{\mathrm{a}}$ \\
\hline \multirow[t]{4}{*}{ Yield (total, \%) } & ABI 04/02 & $16.30 \pm 9.46^{\mathrm{b}}$ & $14.73 \pm 9.39^{\mathrm{b}}$ & $12.80 \pm 8.91^{\mathrm{b}}$ & $15.45 \pm 3.58^{\mathrm{b}}$ & $15.23 \pm 7.55^{\mathrm{b}}$ \\
\hline & ABI $11 / 16$ & $6.36 \pm 1.96^{\mathrm{c}}$ & $5.30 \pm 1.53^{\mathrm{c}}$ & $2.38 \pm 2.54^{\mathrm{c}}$ & $5.22 \pm 1.39^{c}$ & $5.00 \pm 3.16^{\mathrm{c}}$ \\
\hline & ABI $15 / 01$ & $24.30 \pm 4.70^{\mathrm{a}}$ & $24.48 \pm 5.37^{\mathrm{a}}$ & $27.16 \pm 3.12^{\mathrm{a}}$ & $26.35 \pm 3.05^{\mathrm{a}}$ & $22.11 \pm 4.09^{\mathrm{ab}}$ \\
\hline & ABI $15 / 02$ & $22.4 \pm 7.83^{\mathrm{ab}}$ & $19.72 \pm 7.37^{\mathrm{ab}}$ & $21.2 \pm 2.65 \mathrm{a}$ & $22.40 \pm 3.57^{\mathrm{a}}$ & $23.53 \pm 4.87^{\mathrm{a}}$ \\
\hline \multirow[t]{4}{*}{ Weight of mushroom (g) } & ABI 04/02 & $15.17 \pm 4.45^{\mathrm{a} \mathrm{B}}$ & $17.33 \pm 6.46^{\mathrm{a} \mathrm{AB}}$ & $18.34 \pm 3.99^{\mathrm{a} \mathrm{AB}}$ & $22.18 \pm 5.64^{\mathrm{a} A}$ & $20.71 \pm 8.31^{\mathrm{a} \mathrm{AB}}$ \\
\hline & ABI $11 / 16$ & $7.68 \pm 4.61^{\mathrm{b}}$ & $8.52 \pm 5.62^{\mathrm{b}}$ & $7.46 \pm 4.85^{\mathrm{b}}$ & $10.45 \pm 3.23^{\mathrm{b}}$ & $10.31 \pm 3.55^{\mathrm{b}}$ \\
\hline & ABI $15 / 01$ & $14.10 \pm 3.18^{\mathrm{a}}$ & $13.78 \pm 3.22^{\mathrm{ab}}$ & $16.64 \pm 5.99^{\mathrm{a}}$ & $15.48 \pm 3.62^{\mathrm{b}}$ & $15.36 \pm 9.74^{\mathrm{ab}}$ \\
\hline & ABI $15 / 02$ & $11.82 \pm 1.39^{\mathrm{ab}}$ & $12.62 \pm 1.64^{\mathrm{ab}}$ & $13.29 \pm 2.59^{\mathrm{ab}}$ & $12.17 \pm 3.38^{\mathrm{b}}$ & $13.33 \pm 2.41^{\mathrm{b}}$ \\
\hline \multirow[t]{4}{*}{ Number of mushrooms (uni) } & ABI 04/02 & $43 \pm 31^{\mathrm{ab}}$ & $33 \pm 21^{\mathrm{bc}}$ & $28 \pm 23^{\mathrm{b}}$ & $27 \pm 12^{\mathrm{b}}$ & $32 \pm 21^{\mathrm{b}}$ \\
\hline & ABI $11 / 16$ & $19 \pm 12^{b}$ & $16 \pm 13^{c}$ & $10 \pm 11^{\mathrm{b}}$ & $18 \pm 5^{\mathrm{b}}$ & $17 \pm 12^{\mathrm{b}}$ \\
\hline & ABI $15 / 01$ & $62 \pm 16^{\mathrm{a}}$ & $67 \pm 25^{\mathrm{a}}$ & $62 \pm 19^{\mathrm{a}}$ & $63 \pm 18^{\mathrm{a}}$ & $65 \pm 32^{\mathrm{a}}$ \\
\hline & ABI $15 / 02$ & $68 \pm 26^{\mathrm{a}}$ & $56 \pm 22^{\mathrm{ab}}$ & $58 \pm 13^{\mathrm{a}}$ & $67 \pm 13^{\mathrm{a}}$ & $64 \pm 25^{\mathrm{a}}$ \\
\hline
\end{tabular}

Each value is expressed as mean \pm standard deviation $(n=6)$. Values followed by different lower case letters within a column and upper case letters within a line are significantly different at $p<0.05$

due to the positive results obtained in the concentrations of 55 and $5.5 \mathrm{ppm}$. Strain ABI 11/16 and product 3 (concentration of $55 \mathrm{ppm}$ ) were also selected because none showed a stimulus on mycelial growth; therefore, they were used to check for a hormesis effect on in vivo cultivation. In this sense, we named them as test agents. The higher total yield (27.16\%) was observed with ABI 15/01 and product 3 (55 ppm, a.i. kresoxim methyl). This strain showed a slight increase in mycelial growth, but only for product 2 (55 ppm), while product 3 (test agent) did not show any stimulation on mycelial growth for any strain. These results suggest different physiological responses regarding mycelial growth and mushroom yield. In a similar way, the fastest mycelial growth on the mushroom substrate not always results in higher mushroom yield (Siwulski et al. 2010).

The highest stimulus on mycelial growth was verified in the combination of strain ABI 15/02 and product 2/5.5 ppm concentration, with an increase of mycelial growth in the order of $45.5 \%$ compared to the control. However, when this same combination was tested, a negative effect was observed in the in vivo experiment, with a reduction of $16 \%$ on mushroom yield compared to the control.
Considering an in vivo experiment, several factors may contribute directly to the quantitative results involved in mushroom production. Among different factors, we can highlight chemical, physical, microbiological, and environmental factors and their interactions with compost, casing layer, and strains (Mamiro and Royse 2008; Royse and Chalupa 2009; Pardo et al. 2010; Pardo-Gimenez et al. 2016), besides low doses of pesticides, such as those used in this work. The ideal time for application of the fungicides remains as another important subject for future research, either $2,4,6$, or 8 days after casing. It might also be advisable to apply the fungicides between the flushes.

The use of pesticides, such as fungicides, acaricides, and insecticides, is a common practice in the cultivation of A. bisporus, which places this products between the list of highest number of pesticides registered by the regulatory agencies for commercial mushroom cultivation. However, the objective of this manuscript was not to control any pest/ disease, but to verify the effect of the application of reduced doses of fungicides on the physiological behavior of $A$. bisporus. Perhaps this is a tool or alternative to carry out an experiment involving a pest/disease and reduced doses of 
pesticides, to check the effect of the product on the physiological behavior of the mushroom to increase yield and the possible reduction of the pest/disease.

The active ingredient of the product probably has a direct relation with the physiological response of the mushroom. During the first stage, mycelial growth was affected by products 2 (tebuconazole) and 4 (all a.i.), while in the second stage, the most expressive effect on the mushroom yield was observed for product 3 (kresoxim methyl-test agent), followed by product 4 (a.i., including kresoxim methyl). Therefore, we may conclude that tebuconazole was more effective in positively affecting mycelial growth, while kresoxim methyl was more effective in positively affecting mushroom yield. Besides that, strain ABI 15/02 was most positively affected by the fungicide treatment, followed by ABI 15/01, concerning mycelial growth. On the other hand, considering mushroom yield, strain ABI 15/01 was the most positively affected by the fungicide treatment, while ABI 15/02 was not positively affected or showed a decrease of mushroom yield. Therefore, strain ABI 15/01 may be a very useful model for futures hormesis studies.

Although the hormesis effect is known in medicinal, pharmacological, and agronomical science, it has no practical definite application for technological development on mushroom cultivation. Further studies should be performed to clarify the mechanisms of the hormesis effect, such as transcriptome analysis, to better understand the process and to suggest an adequate management strategy for commercial production of A. bisporus.

Acknowledgements We would like to thank the Fundação de Amparo a Pesquisa do Estado de São Paulo for financial support (FAPESP 14/18680-0).

\section{Compliance with ethical standards}

Conflict of interest The authors declare that they have no conflict of interest.

\section{References}

Calabrese EJ, McCarthy ME, Kenyon E (1987) The occurrence of chemically induced hormesis. Health Phys 52(5):531-541

Clough JM (2000) The strobilurin fungicides-from mushroom to molecule to market. Spec Publ Roy Soc Chem 257:277-282

Gea FJ, Tello JC, Navarro MJ (2010) Efficacy and effects on yield of different fungicides for control of wet bubble disease of mushroom caused by the mycoparasite Mycogone perniciosa. Crop Prot 29(9):1021-1025
Grogan HM, Jukes AA (2003) Persistence of the fungicides thiabendazole, carbendazim and prochloraz-Mn in mushroom casing soil. Pest Manag Sci 59(11):1225-1231

Hammond JBW, Nichols R (1976) Carbohydrate metabolism in Agaricus bisporus (Lange) Sing.: changes in soluble carbohydrates during growth of mycelium and sporophore. J Gen Microbiol 93:309-320

Klittich CJ (2008) Milestones in fungicide discovery: chemistry that changed agriculture. Plant Health Progress. doi:10.1094/ PHP-2008-0418-01-RV

Kosanović D, Potočnik I, Vukojević J, Stajić M, Rekanović E, Stepanović M, Todorović B (2015) Fungicide sensitivity of Trichoderma spp. from Agaricus bisporus farms in Serbia. J Environ Sci Health B 50(8):607-613

Luckey TD (1982) Physiological benefits from low levels of ionizing radiation. Health Phys 43(6):771-789

Mamiro DP, Royse DJ (2008) The influence of spawn type and strain on yield, size and mushroom solids content of Agaricus bisporus produced on non-composted and spent mushroom compost. Bioresour Technol 99:3205-3212

Pardo A, Pardo JE, de Juan JA, Zied DC (2010) Modelling the effect of the physical and chemical characteristics of the materials used as casing layers on the production parameters of Agaricus bisporus. Arch Microbiol 192(12):1023-1030

Pardo-Giménez A, Catalán JLC, Álvarez-Ortí M, Zied DC, Pardo JE (2016) Effect of supplementing crop substrate with defatted pistachio meal on Agaricus bisporus and Pleurotus ostreatus production. J Sci Food Agr 96:3838-3845

Reis EM, Zanatta M, Carmona M, Menten JO M (2015) Relationship between IC50 determined in vitro/in vivo and the fungicide rate used in the Field. Summ Phytopathol 41:49-53

Royse DJ, Chalupa W (2009) Effects of spawn, supplement and phase II compost additions and time of re-casing second break compost on mushroom (Agaricus bisporus) yield and biological efficiency. Bioresour Technol 100(21):5277-5282

Sagan LA (1991) Radiation hormesis: evidence for radiation stimulation and speculation regarding mechanisms. Int J Radiat Appl Instrum Part C Radiat Phys Chem 37(2):313-317

Siwulski M, Sobieralski K, Makowski J (2010) Comparison of mycelium growth of selected species of cultivated mushrooms on textile industry wastes. Acta Sci Pol Hortorum Cultus 9:37-43

Yoder JB, Sinden JW, Hauser E (1951) Experience with zinc ethylene bis-dithiocarbamate as a fungicide in mushroom cultivation. Mushroom Sci 1(1):100-108

Zied DC, Minhoni MTA, Kopytowski-Filho J, Andrade MCND (2010) Production of Agaricus blazei ss. Heinemann (A. brasiliensis) on different casing layers and environments. World J Microbiol Biotechnol 26(10):1857-1863

Zied DC, Pardo-Gonzalez JE, Minhoni MTA, Pardo-Gimenez A (2011) A reliable quality index for mushroom cultivation. J Agric Sci 3(4):50-61

Zied DC, Penachio SM, Dias ES, Minhoni MTA, Ferraz RA, Vieites RL (2014) Influence of productivity and processing method on physicochemical characteristics of white button mushrooms in Brazil. J Sci Food Agr 94(14):2850-2855

Zied DC, Nunes JS, Nicolini VF, Pardo-Giménez A, Rinker DL, Dias ES (2015) Tolerance to Lecanicillium fungicola and yield of Agaricus bisporus strains used in Brazil. Sci Hortic 190:117-122 